\title{
Studies of red cell cation transport in white and black essential hypertensives
}

\author{
K. L. Woods* \\ M.D., M.R.C.P. \\ M. J. WEST* \\ B.Sc. \\ P. L. WEISSBERG* \\ M.B., M.R.C.P. \\ D. G. BEEVERS $†$ \\ M.D., F.R.C.P. \\ *Department of Therapeutics and Clinical Pharmacology, University of Birmingham, and
†Department of Medicine, Dudley Road Hospital, Birmingham
}

\begin{abstract}
Summary
It has been reported previously in white patients with essential hypertension that red cell sodium pump activity as measured by ouabain-sensitive uptake of the potassium analogue ${ }^{86} \mathbf{R b}$ from a potassium-free medium, is very significantly greater than in white controls. In a further study of black (West Indian) subjects reported here no similar abnormality was present in black hypertensives when compared with black normotensive individuals. Red cell rubidium uptake was significantly lower in normotensive blacks than in normotensive whites although sodium pump activity was the same. These results may be relevant to observed racial differences in sodium handling and in the pathophysiology of essential hypertension.
\end{abstract}

\section{Introduction}

There is now a large body of evidence to indicate that in whites with essential hypertension the distribution of sodium between intra-cellular and extracellular compartments is abnormal and a number of cation transport abnormalities have been described in both erythrocytes and leucocytes (Garay et al., 1980; Poston et al., 1981). The mechanism underlying these abnormalities is disputed. It has recently been reported from this laboratory that there is an apparent increase in the activity of the erythrocyte sodium-potassium ATPase ('sodium pump') in essential hypertensive whites although this is probably secondary to raised intracellular sodium (Woods, Beevers and West, 1981). Preliminary work suggested racial differences in normal red cell electrolyte transport which has now been examined in more detail.

When normotensive black and white individuals are given an i.v. saline load the former group excrete sodium more slowly and have a greater and more sustained rise in blood pressure while doing so (Luft et al., 1979). This difference in natriuretic response might account for the greater prevalence of essential hypertension among blacks than among whites living in similar urban environments with a high dietary sodium intake (Stamler et al., 1974; Sever et al., 1979). Essential hypertension in blacks is more commonly associated with low plasma renin than in whites (Dunn and Tannen, 1974; Brunner et al., 1972) and has been reported to be less responsive to $\beta$-blockade (Seedat, 1980). These indications of pathogenetic and pathophysiological differences in essential hypertension among blacks and whites prompted the present study in which red cell cation transport was compared in matched groups of normotensives and hypertensives from both races resident in the catchment area of a single hospital.

\section{Methods}

The ${ }^{86}$ rubidium $\left({ }^{86} \mathrm{Rb}\right)$ procedure has been described previously (Woods et al., 1981) and was based on the method of Aronson et al. (1977). Washed red cells were suspended in potassium-free Ringer's solution containing $3 \mu \mathrm{mol} / \mathrm{l}^{86} \mathrm{Rb}$ chloride and uptake of the isotope was measured over one $\mathrm{hr}$ at $37^{\circ} \mathrm{C}$ in the presence and absence of ouabain $1 \mathrm{mg} / \mathrm{ml}$. The inter- and intra-assay coefficients of variation were $<5 \%$. The non-parametric MannWhitney test was used to compare all uptake data.

None of the subjects included in the study was taking any prescribed or proprietary drug treatment. The hypertensive individuals were newly referred cases who had received no anti-hypertensive treatment for at least 6 weeks and the great majority had never been treated for hypertension. Their blood pressures were in excess of $140 / 90 \mathrm{mmHg}$ (diastolic V). Whites and blacks were well matched for blood pressure (177/106 and $178 / 104 \mathrm{mmHg}$ respectively) and were also of similar age (mean 47 and 50 years respectively). The normotensive controls 
included patients awaiting minor surgical procedures, factory workers taking part in blood pressure screening, and medical and laboratory staff. None of the controls had any known or suspected family history of hypertension. Black and white controls were also well matched for blood pressure (124/76 and $119 / 74 \mathrm{mmHg}$ respectively) and mean age (35 years for both groups). Each group contained approximately equal numbers of males and females. Earlier studies had failed to show any influence of either age or sex on ${ }^{86} \mathrm{Rb}$ uptake.

\section{Results}

The pooled results are shown in Fig. 1. Total ${ }^{86} \mathrm{Rb}$ uptake was significantly greater in normotensive whites than in normotensive blacks owing to a very significantly greater ouabain-resistant ${ }^{86} \mathbf{R b}$ uptake in the whites. Ouabain-sensitive transport of ${ }^{86} \mathrm{Rb}$ was identical in the 2 groups. Ouabainresistant influx includes passive movement of ${ }^{86} \mathrm{Rb}$ into the cells and also several saturatable pathways. It is not yet clear which of these is responsible for the racial difference in normotensives.

When white hypertensives were compared with white normotensive controls a very significant increase in sodium pump activity was found in the former as has been reported previously. Ouabainresistant ${ }^{86} \mathrm{Rb}$ transport was identical in white hypertensives and white normotensives.

When black hypertensives were compared with black normotensive controls there was no abnormality in either component of ${ }^{86} \mathrm{Rb}$ influx under the conditions of the experiment. This is in clear con $\frac{\pi}{0}$ trast to the results found in white essential hyper tensives. Sodium pump transport of ${ }^{86} \mathrm{Rb}$ was in fact: lower in black hypertensives than in black controls although this difference did not reach significanceo

\section{Discussion}

The increased red cell sodium pump activit $\bar{g}$ observed among white essential hypertensives mat well be a secondary phenomenon in response to another abnormality in transmembrane sodiun $P$ movement such as a defect in the sodium-potassium $\vec{F}$ co-transport mechanism described by Garay et af (1980) or even an increase in membrane sodiung permeability as suggested by Postnov et al. (1977) 3 . Whatever the explanation, it is of great interest thaty no similar change was seen in black hypertensives in comparison with normotensive black controls $\$$ These contrasting results suggest either that there is no abnormality in cation movement across the redo cell membrane in black hypertensives or, alterna은 tively, that there is a defect but one which is different from that occurring in white hypertensives and nog detected by the technique used here. The latte possibility is supported by the observation of Ader 3 ounmu and Salako (1979) that red cell sodium conn centration is indeed significantly higher in hyper:tensive than in normotensive Nigerians. A furfebo understanding of the physiological basis for differences in electrolyte transport between normo응 tensive blacks and whites and between normotensives and hypertensive whites may clarify the interaction

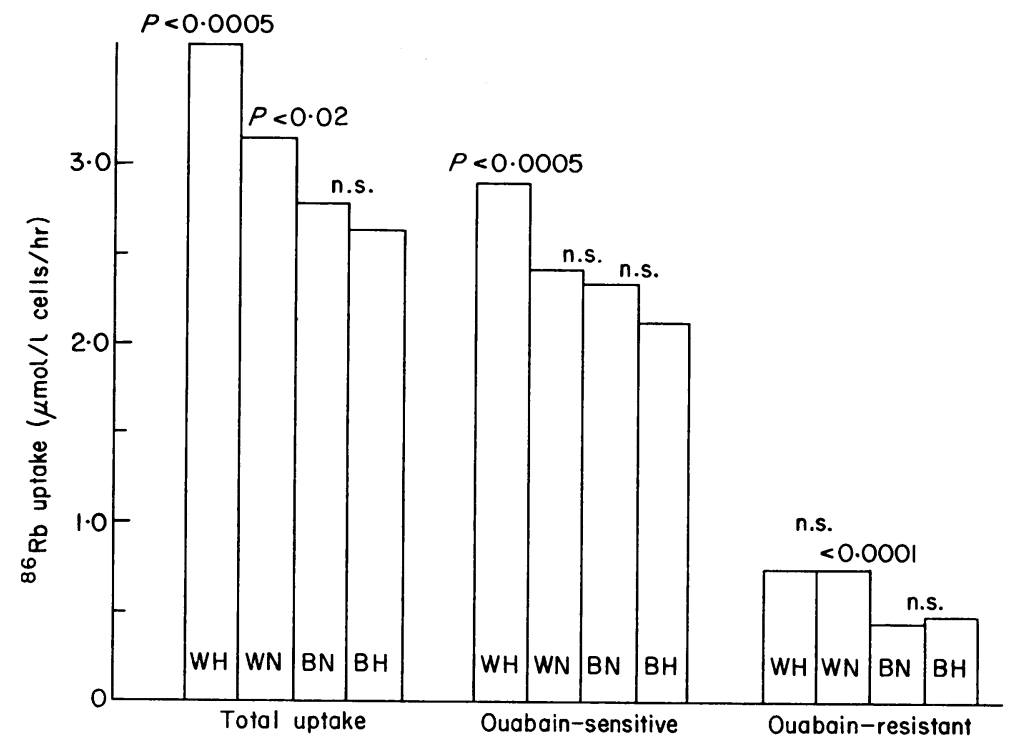

FIG 1. Pooled uptake data for white hypertensives (WH) $(n=16)$, white normotensives (WN) $(n=22)$, black normotensives ${ }^{-}$ (BN) $(n=23)$ and black hypertensives $(\mathrm{BH})(n=10)$. Statistics by Mann-Whitney test. 
between genetic and environmental factors in the development of essential hypertension.

\section{References}

Aderounmu, A.F. \& Salako, L.A. (1979) Abnormal cation composition and transport in erythrocytes from hypertensive patients. European Journal of Clinical Investigation, 9, 369.

Aronson, J.K., Grahame-Smith, D.G., Hallis, K.F., Hibble, A. \& Wigley, F. (1977) Monitoring digoxin therapy: 1. Plasma concentrations and an in vitro assay of tissue response. British Journal of Clinical Pharmacology, 4, 213.

Brunner, H.R., Laragh, J.H., Baer, L., Newton, M.A., Goodwin, F.T., Krakoff, L.R., BARD, R.H. \& BuHLER, F.R. (1972) Essential hypertension, renin and aldosterone, heart attack and stroke. New England Journal of Medicine, 286, 441.

DunN, M.J. \& TANnen, R.L. (1974) Low-renin hypertension. Kidney International, 5, 317.

Garay, R.P., Dagher, G., Pernollet, M.-G., Devynck, M.-A. \& MeYeR, P. (1980) Inherited defect in a $\mathrm{Na}^{+} / \mathrm{K}^{+}$ co-transport system in erythrocytes from essential hypertensive patients. Nature, 284, 281.

Luft, F.C., Grim, C.E., Fineberg, N. \& Weinberger, M.C.
(1979) Effects of volume expansion and contraction in normotensive whites, blacks and subjects of different ages. Circulation, 59, 643.

Postnov, Y.V., Orlov, S.N., Shevchenko, A. \& Adler, A.M. (1977) Altered sodium permeability, calcium binding and $\mathrm{Na}^{+} / \mathrm{K}^{+}$ATPase activity in the red blood cell membrane in essential hypertension. Pflïgers Archiv für die gesamte Physiologie des Menschen und der Tiere, 371, 263.

Poston, L., Sewell, R.B., Wilkinson, S.P., Richardson, P.J., Williams, R., Clarkson, E.M., MacGregor, G.A. \& DE WARDENER, H.E. (1981) Evidence for a circulating sodium transport inhibitor in essential hypertension. British Medical Journal, 282, 847.

SEeDAT, Y.K. (1980) Trial of atenolol and chlorthalidone for hypertension in black South Africans. British Medical Journal, 281, 1241.

Sever, P.S., Peart, W.S., Meade, T.W., Davies, I.B. \& GoRDON, D. (1979) Ethnic differences in blood pressure with observations on noradrenaline and renin. 1. A working population. Clinical and Experimental Hypertension, 1, 733.

Stamler, J., Schoenberger, J.A., Shekelle, R.D. \& StAMLER, R. (1974) The Hypertension Handbook. Merck, Sharp and Dohme, West Point, Pennsylvania, 3.

Woods, K.L., BeEvers, D.G. \& WeST, M. (1981) Familial abnormality of erythrocyte cation transport in essential hypertension. British Medical Journal. 282, 1186. 